$\$ \begin{aligned} & \text { JOURNAL OF SURIMI } \\ & \text { (SUSTAINABLE RESEARCH IN MANAGEMENT OF AGROINDUSTRI) } \\ & \begin{array}{l}\text { Homepage : } \text { https://ejournal.pnc.ac.id/index.php/surimi/index } \\ \text { e-ISSN 2776-7280 dan p-ISSN 2776-7272 }\end{array}\end{aligned}$

\title{
Efektivitas Pemberian Limbah Biogas Sapi Terhadap Kadar Protein Jerami Jagung Untuk Pakan Ternak
}

\section{[The Effectiveness of Cattle Biogas Waste on Corn Straw Protein Levels for Animal Feed]}

\author{
Sari Widya Utami ${ }^{1 *}$, dan Ari Kristiningsih ${ }^{2)}$ \\ 1,2 Program Studi D4 Pengembangan Produk Agroindustri, Politeknik Negeri Cilacap \\ Jl. Dr. Soetomo No.1, Sidakaya-Cilacap 53212 Jawa Tengah, Indonesia \\ * Email korespondensi : sariwidyautami@ gmail.com \\ Dikirim : 2021-09-26 \\ Direvisi : 2021-12-28 \\ Diterima : 2022-01-27
}

ABSTRACT

Plant-livestock integration was one of the concepts of integrated agriculture. Agricultural waste had the potential to be developed as animal feed material, such as corn straw. The availability of waste, such as agricultural, livestock and biogas wil pollute the environment if it is not utilized. Therefore, the purpose of this study was to determine the effect of giving biogas waste on the protein content of corn straw, as a by-product of corn cultivation. The treatment in this study used two factors, namely (i) cow biogas solid waste consisting of 2 treatment levels, namely 0 and 5.4 tons/ha, and (ii) cow biogas liquid waste consisting of 4 treatment levels, namely 0 liter/ha. , 500 liters/ha, 1000 liters/ha and 1500 liters/ha. The data measured were nitrogen content, nitrogen absorption and protein content of corn straw. The results showed that the application of biogas waste was able to increase the protein content of corn straw.

Keywords: biogas waste, protein, corn-straw

\section{ABSTRAK}

Integrasi tanaman-ternak menjadi salah satu konsep pertanian terpadu. Limbah pertanian memiliki potensi untuk dikembangkan sebagai bahan pakan ternak, seperti jerami jagung. Ketersediaan limbah baik limbah pertanian, peternakan maupun biogas akan mencemari lingkungan jika tidak dimanfaatkan. Oleh karena itu tujuan dari penelitian ini adalah untuk mengetahui pengaruh pemberian limbah biogas terhadap kadar protein jerami jagung, sebagai produk samping dari budidaya jagung. Perlakuan pada penelitian ini menggunakan dua faktor yaitu (i) limbah padat biogas sapi yang terdiri dari 2 aras perlakuan yaitu 0 dan 5,4 ton/ha, dan (ii) limbah cair biogas sapi yang terdiri dari 4 aras perlakuan yaitu 0 liter/ha, 500 liter/ha, 1000 liter/ha dan 1500 liter/ha. Data yang diukur berupa kadar Nitrogen, Serapan Nitrogen dan kadar protein jerami jagung. Hasil penelitian menunjukkan pemberian limbah biogas mampu meningkatkan kadar protein jerami jagung.

Kata kunci: Limbah Biogas, Protein, Jerami Jagung

\section{Pendahuluan}

Konsep integrated farming dengan menggunakan metode zero waste management adalah salah satu sistem kerjasama yang baik antara ternak-tanaman. Kontribusi tanaman bagi ternak yaitu limbah dari tanaman dapat digunakan bahan pakan ternak. Limbah peternakan akan menyebabkan polusi lingkungan apabila tidak dikelola dengan baik. Limbah peternakan akan lebih bermanfaat apabila diolah menjadi produk lain seperti pupuk kandang dan biogas. Pada usaha peternakan skala besar seringkali limbah ternak diolah menjadi biogas. Proses pengolahan biogas tersebut masih menghasilkan limbah, yaitu sludge. Sludge yang dibiarkan saja akan mencemari lingkungan, oleh karena itu sludge dapat dimanfaatkan sebagai pupuk bagi tanaman.

Bahan pakan ternak yang berkualitas menjadi salah satu faktor penentu kualitas produk ternak yang dihasilkan. Bahan pakan yang digunakan banyak berasal dari limbah pertanian, salah satunya adalah limbah tanaman jagung. Limbah tanaman jagung yang berupa jerami segar menjadi salah satu 
bahan pakan utama untuk ternak ruminansia, yang dapat dicampur dengan bahan lain seperti dedak, polar dan molase.

Limbah budidaya tanaman jagung yang berupa jerami sangat potensial untuk digunakan sebagai bahan pakan ternak, khususnya ruminansia. Menurut Erawati dan Hipi (2011), penggunaan jerami jagung semakin meningkat karena berkurangnya ketersediaan hijauan akibat keterbatasan lahan dan berkembangnya populasi ternak (ruminansia). Meskipun jerami jagung merupakan hasil samping dari budidaya jagung, akan tetapi sebagai bahan pakan ternak, nutrisi yang terdapat didalamnya menjadi hal yang penting untuk diketahui. Bahan pakan dengan nutrisi yang baik akan mempengaruhi kualitas hasil dengan nutrisi yang tinggi. Salah satu nutrisi bahan pakan yang penting adalah protein. Protein merupakan salah satu penentu kualitas susu (Prihatiningsih, dkk, 2015). Protein merupakan salah satu parameter kualitas nutrisi bahan pakan. Protein tersusun atas asam amino, dimana penyusun utama asam amino adalah nitrogen. Seperti yang disampaikan Finar (1975), komposisi protein terdiri dari : 46-55\% $\mathrm{C} ; 6-9 \% \mathrm{H} ; 12-30 \% \mathrm{~N} ; 0,2-0,3 \% \mathrm{~S}$; dan unsur lain seperti P (nucleoprotein) dan Fe (haemoglobin). Rata-rata protein tanaman mengandung $16 \% \mathrm{~N}$ yang terkandung di dalamnya (Marschner, 1986). Hal ini menunjukan keterkaitan antara kualitas bahan pakan ternak dengan produk ternak yang dihasilkan.

Tujuan penelitian ini adalah untuk mengetahui pengaruh pemberian pupuk dari limbah biogas sapi terhadap kadar protein jerami jagung. Manfaat dari penelitian ini adalah diharapkan dapat memberikan informasi tentang pemanfaatan pupuk limbah biogas sapi terhadap kadar protein jerami jagung yang merupakan salah satu bahan pakan ternak.

\section{Metode Penelitian}

Penelitian ini merupakan percobaan lapangan yang dilaksanakan di Kebun Percobaan Penelitian dan Pengembangan Pertanian (KP4) UGM di Kalitirto, Brebah, Sleman, Yogyakarta. Analisis limbah biogas sapi dilaksanakan di Laboratorium Tanah umum dan Kesuburan Tanah Kuningan Fakultas Pertanian UGM. Penelitian dilaksanakan mulai bulan Juli 2013 sampai dengan April 2014.

Bahan yang digunakan dalam penelitian ini adalah limbah padat dan cair dari biogas sapi Bali, tanah Inceptisol Kalitirto, benih jagung manis (varietas sweat boy), bahan-bahan kimia untuk analisa tanaman dan pupuk. Alat yang digunakan dalam penelitian ini meliputi alat untuk penelitian di lapang dan alat-alat untuk analisis di laboratorium.

Rancangan perlakuan berupa faktorial lengkap yang terdiri dari 2 faktor. Faktor pertama adalah dosis limbah padat biogas sapi Bali yang terdiri dari 2 aras perlakuan yaitu 0 ton/ha (P0) dan 5,4 ton/ha (P1). Faktor ke dua adalah dosis pupuk limbah cair biogas sapi Bali yang terdiri dari 4 aras perlakuan yaitu 0 liter/ha (D0), 500 liter/ha (D1), 1000 liter/ha (D2) dan 1500 liter/ha (D3). Jumlah pengulangan ditentukan sebanyak tiga kali, sehingga dalam penelitian ini didapatkan 24 petak percobaan. Rancangan lingkungan diatur dengan rancangan acak kelompok lengkap (RAKL).

Limbah padat biogas diberikan pada ke tanah sebagai pupuk dasar. Aplikasi limbah cair ini dilakukan pengenceran 1:5 yaitu 1 liter limbah cair dengan 5 liter air. Pupuk limbah cair biogas diaplikasikan dengan cara dikocor ke tanah seminggu sekali mulai dari minggu ke-4 sampai dengan minggu ke-8 setelah tanam. Pupuk kimia tetap diberikan karena status hara tanah yang digunakan cukup rendah yaitu $0,1 \% \mathrm{~N} ; 16,31 \mu \mathrm{g} / \mathrm{g}$ P dan $0,09 \mathrm{cmol}(+) \mathrm{kg}^{-1} \mathrm{~K}$. Rekomendasi pemupukan untuk jagung manis adalah urea $300 \mathrm{~kg} / \mathrm{ha}$, SP36 $150 \mathrm{~kg} / \mathrm{ha}$ dan $\mathrm{KCl} 50 \mathrm{~kg} / \mathrm{ha}$ (Ziraida, 2010).

Analisis jaringan tanaman yang berupa jerami jagung diambil pada fase vegetatif maksimum (50 HST). Kandungan protein jerami jagung dianalisis dengan metode konversi $\mathrm{N}$ jerami (Sudarmaji, $d k k$, 1997). Kadar N dianalisis dengan metode Kjedahl (Balai Penelitian Tanah, 2009). Analisis data menggunakan uji keragaman Fisher. Apabila nilainya berbeda nyata dilanjutkan dengan uji beda nyata menurut Duncan Multiple Range Test (DMRT) dengan tingkat kepercayaan 95\%.

\section{Hasil dan Pembahasan}

Kadar dan Serapan Nitrogen Jerami jagung

Interaksi antara limbah padat biogas dan limbah cair biogas mempengaruhi kadar hara dan serapan N Jerami (Tabel 1). Penambahan hara melalui aplikasi limbah padat dan cair biogas sapi secara tunggal mampu meningkatkan kadar hara dan serapan $\mathrm{N}$ jerami dibandingkan dengan kontrol.

Berdasarkan Tabel 1, nilai tertinggi untuk kadar $\mathrm{N}$ jerami didapatkan pada perlakuan limbah padat biogas dan limbah cair biogas dosis 1000 liter/ha yaitu 1,7\%. Lebih tingginya dosis limbah cair yang diperlukan untuk peningkatan kadar $\mathrm{N}$ pada jerami diduga terkait dengan distribusi hara $\mathrm{N}$ yang 
diserap, karena biomassa di atas permukaan tanah lebih besar dibanding di bawah permukaan tanah (akar). Interaksi yang terjadi pada akar dan trubus tanaman diduga karena pada fase vegetatif maksimum dimana sampel ini di ambil, merupakan fase yang paling optimal bagi tanaman jagung manis dalam menyerap unsur hara N. Pemberian kedua jenis limbah biogas tersebut berkontribusi terhadap banyaknya kadar $\mathrm{N}$ yang diserap tanaman jagung manis. Hal ini diperkuat bahwa baik limbah padat maupun cair, perlakuan tunggal kedua limbah tersebut memberikan pengaruh yang signifikan. Pemberian limbah cair biogas mempunyai kadar $\mathrm{N}$ tertinggi pada dosis 1000 liter/ha dan kemudian mengalami penurunan ketika dosis dinaikkan. Hal tersebut menunjukan pada dosis tersebut telah mencapai dosis optimum.

Tabel 1. Pengaruh pemberian limbah padat biogas dan limbah cair biogas terhadap kadar dan serapan N Jerami jagung

\begin{tabular}{lcl}
\hline Perlakuan & Kadar N $(\%)$ & Serapan N (g/tanaman) \\
\hline Perlakuan limbah padat dan limbah cair biogas & \\
Kontrol & $0,75 \mathrm{c}$ & $0,49 \mathrm{~d}$ \\
0 ton/ha +500 liter/h & $1,33 \mathrm{~b}$ & $1,07 \mathrm{a}$ \\
0 ton/ha +1000 liter/ha & $1,21 \mathrm{~b}$ & $0,80 \mathrm{bc}$ \\
0 ton/ha +1500 liter/ha & $1,17 \mathrm{~b}$ & $0,71 \mathrm{~cd}$ \\
5,4 ton/ha +0 liter/ha & $1,35 \mathrm{~b}$ & $0,99 \mathrm{ab}$ \\
5,4 ton/ha +500 liter/ha & $1,47 \mathrm{ab}$ & $1,17 \mathrm{a}$ \\
5,4 ton/ha +1000 liter/ha & $1,70 \mathrm{a}$ & $1,22 \mathrm{a}$ \\
5,4 ton/ha +1500 liter/ha & $1,17 \mathrm{~b}$ & $0,80 \mathrm{bc}$ \\
\hline Interaksi & $(+)$ & $(+)$ \\
\hline Dosis limbah padat biogas & & \\
0 ton/ha & $1,11 \mathrm{~b}$ & $0,77 \mathrm{~b}$ \\
5,4 ton/ha & $1,42 \mathrm{a}$ & $1,04 \mathrm{a}$ \\
\hline Dosis limbah cair biogas & & \\
0 liter/ha & $1,05 \mathrm{~b}$ & $0,74 \mathrm{~b}$ \\
500 liter/ha & $1,40 \mathrm{a}$ & $1,12 \mathrm{a}$ \\
1000 liter/ha & $1,46 \mathrm{a}$ & $1,00 \mathrm{a}$ \\
1500 liter/ha & $1,17 \mathrm{~b}$ & $0,76 \mathrm{~b}$ \\
\hline
\end{tabular}

Keterangan : angka-angka dalam kolom yang sama diikuti oleh huruf yang sama tidak berbeda nyata pada uji Duncan (DMRT) dengan tingkat ketelitian $95 \%$. ( + ) menunjukkan interaksi nyata.

Perlakuan limbah padat biogas 5,4 ton/ha dan limbah cair 1000 liter/ha mampu memberikan nilai yang tertinggi pada serapan hara $\mathrm{N}$ yaitu sebesar 1,22 g/tanaman yang menunjukan bahwa pada kombinasi kedua perlakuan tersebut merupakan dosis optimum. Hal ini diduga karena peningkatan ketersediaan $\mathrm{N}$ pada daaerah perakaran akibat peningkatan dosis limbah cair biogas mampu meningkatkan kadar hara pada biji. Menurut Marschner (1986), peningkatan suplai N pada akar, mempengaruhi kadar $\mathrm{N}$ biji secara tidak langsung melalui retranslokasi dari pertumbuhan vegetatif.

Pemberian limbah padat dan limbah cair secara tunggal menunjukkan perbedaan yang signifikan. Pemberian limbah padat dosis 5,4 ton/ha mempunyai nilai serapan $\mathrm{N}$ lebih tinggi dibanding dengan kontrol. Hal ini menunjukkan limbah padat biogas mampu meningkatkan serapan $\mathrm{N}$ Jerami jagung. Peningkatan serapan $\mathrm{N}$ pada perlakuan limbah padat biogas disebabkan karena ketersediaan $\mathrm{N}$ juga meningkat. Dosis limbah cair 500 liter/ha memberikan serapan $\mathrm{N}$ jerami sebesar 1,1,2 g/tanaman, dan ketika dosis ditingkatkan terjadi penurunan serapan $\mathrm{N}$.

Kadar protein jerami jagung

Berdasarkan Tabel 2, kadar protein terbesar terdapat pada perlakuan dosis limbah padat biogas 5,4 ton/ha yang dikombinasikan dengan perlakuan limbah cair sebesar 1000 liter/ha yaitu sebesar 10,65 $\%$. Pemberian limbah padat biogas secara mandiri mampu meningkatkan kadar protein jerami sebanyak $28 \%$ dibanding tanaman yang tidak diberi limbah padat biogas. Pemberian limbah cair biogas mempunyai kadar $\mathrm{N}$ tertinggi pada dosis 1000 liter/ha dan kemudian mengalami penurunan ketika dosis dinaikkan. Hal tersebut menunjukan pada dosis limbah cair tersebut telah mencapai dosis optimum. 
Tabel 2. Pengaruh perlakuan limbah biogas sapi terhadapa kadar protein (\%) jerami

\begin{tabular}{cccccc}
\hline Limbah padat biogas sapi & \multicolumn{3}{c}{ Limbah cair biogas sapi (liter/ha) } & \multirow{2}{*}{ Rerata } \\
\cline { 2 - 5 } (ton/ha) & 0 & 500 & 1000 & 1500 & \\
\hline 0 & $4,67 \mathrm{c}$ & $8,31 \mathrm{~b}$ & $7,58 \mathrm{~b}$ & $7,30 \mathrm{~b}$ & $6,97 \mathrm{~b}$ \\
5,4 & $8,46 \mathrm{~b}$ & $9,19 \mathrm{ab}$ & $10,65 \mathrm{a}$ & $7,29 \mathrm{~b}$ & $8,90 \mathrm{a}$ \\
\hline Rerata & $6,57 \mathrm{c}$ & $8,75 \mathrm{ab}$ & $9,12 \mathrm{a}$ & $7,29 \mathrm{bc}$ & $(-)$ \\
\hline
\end{tabular}

Keterangan : angka-angka dalam baris dan kolom yang sama diikuti oleh huruf yang sama tidak berbeda nyata pada uji Duncan (DMRT) dengan tingkat ketelitian $95 \%$. ( - ) menunjukkan interaksi tidak nyata.

Peningkatan kadar protein jerami jagung manis akibat pemberian limbah padat dan cair biogas diduga disebabkan adanya peningkatan kandungan $\mathrm{N}$ tanah. Ketersediaan $\mathrm{N}$ tanah yang lebih tinggi pada perlakuan pemberian limbah padat biogas terkait dengan proses mineralisai $\mathrm{N}$-organik yang terdapat dalam limbah tersebut. Menurut Winarso (2005), peningkatan dosis pemupukan $\mathrm{N}$ dalam tanah secara langsung dapat meningkatkan kadar protein $(\mathrm{N})$ dan produksi tanaman jagung.

Sifat dari pupuk organik yang slow release menyebabkan tanaman tidak mengalami defisiensi $\mathrm{N}$ selama proses pertumbuhannya. Pada tanaman yang tidak diberi limbah padat biogas, sumber hara hanya berasal dari hara $\mathrm{N}$ asli tanah dan dari pupuk urea yang memang kandungan $\mathrm{N}$ nya mudah hilang. Kadar $\mathrm{N}$ tanah yang tinggi menyebabkan serapan $\mathrm{N}$ tinggi, sehingga protein yang dihasilkan juga tinggi. Salah satu fungsi unsur $\mathrm{N}$ adalah penyusun protein ( Pritchard, 2005 ) sehingga $\mathrm{N}$ meningkatkan kadar protein secara langsung (Glendinning, 2000), dimana protein mengandung 12-30 \% N (Finar, 1975). Peningkatan kadar protein jerami jagung dengan pemberian limbah biogas sapi baik limbah padat maupun limbah cairnya merupakan tolok ukur keefektifan limbah biogas sapi tersebut. Rata-rata protein jerami jagung dengan pemberian limbah padat biogas mampu mencapai 8,90\%, sedangkan dengan pemberian limbah cair biogas mencapai 8,31\%. Data penelitian (Langoy, $d k k$., 2012) menyebutkan rata-rata kandungan protein kasar jerami jagung yaitu $4,72 \%$.

Hubungan serapan $\mathrm{N}$ dengan besarnya kadar protein pada jerami jagung manis dapat dilihat pada gambar 1 . Korelasi besarnya serapan $\mathrm{N}$ dengan kadar protein yaitu dengan nilai $\mathrm{r}^{2}$ sebesar 0,91 . Angka tersebut menunjukkan korelasi yang kuat, yaitu semakin besar serapan $\mathrm{N}$ pada jerami jagung maka semakin besar kadar protein yang dihasilkan.

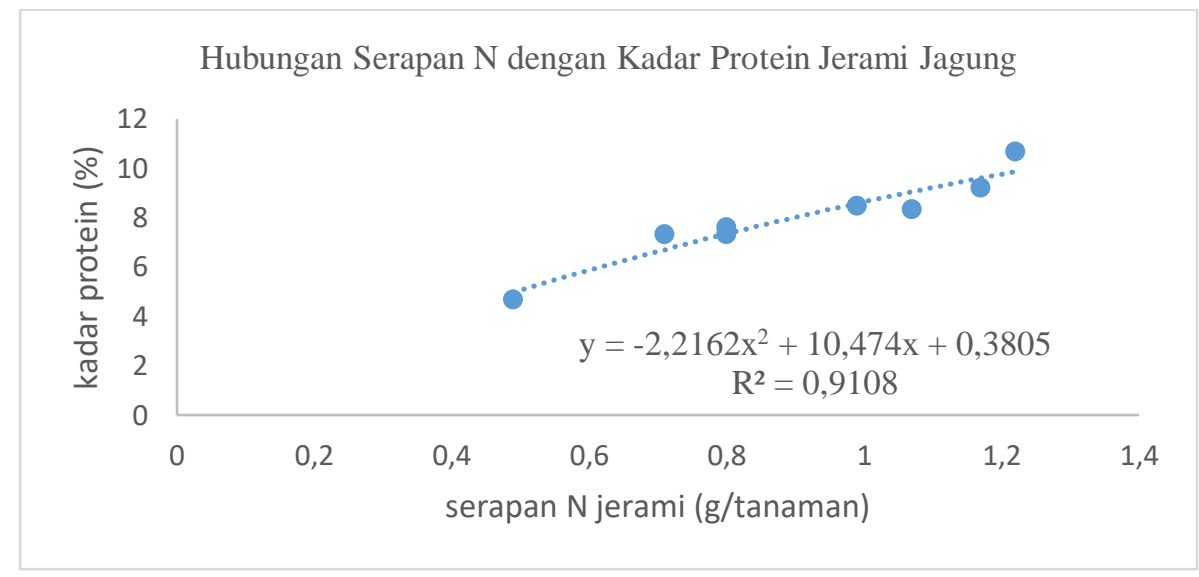

Gambar 1. Grafik hubungan serapan hara $\mathrm{N}$ dengan kadar protein jerami

\section{Kesimpulan}

Peningkatan ketersedian hara tanah akibat pemberian pupuk limbah biogas sapi mampu meningkatkan kadar protein Jerami jagung yang dapat dimanfaatkan sebagai pakan ternak. Pemberian limbah padat dan cair biogas sapi secara tunggal mampu meningkatkan kadar protein Jerami jagung. Pemberian limbah padat biogas sapi sebesar 5,4 ton/ha memberikan kadar protein sebesar 8,9\%. Limbah cair biogas sapi memberikan kadar protein Jerami jagung tertinggi pada dosis 1000 liter/ha dan kemudian mengalami penurunan ketika dosis ditingkatkan. Hal ini menunjukkan efektivitas pemberian limbah biogas baik padat maupun cair dalam meningkatkan kadar protein Jerami jagung, yang merupakan produk samping dari budidaya tanaman jagung. 


\section{Ucapan Terima Kasih}

Penulis mengucapkan terima kasih kepada Tuhan Yang Maha Esa dan semua pihak yang telah membantu kegiatan penelitian ini sehingga bisa terlaksana dengan baik yang terlibat secara langsung maupun tidak langsung hingga jurnal ini dapat diterbitkan.

\section{Daftar Pustaka}

Baiq Tri Ratna Erawati dan A. Hipi. (2011). Potensi Beberapa Varietas Jagung Dan Limbahnya Sebagai Pakan Ternak Dalam Mendukung Pengembangan Sejuta Sapi Di Nusa Tenggara Barat. Seminar Nasional Teknologi Peternakan Dan Veteriner. 265-270.

Balai Penelitian Tanah. (2009). Petunjuk Teknis Analisis Kimia Tanah, Tanaman, Air dan Pupuk. Balai Penelitian Tanah, Bogor. Bogor: Balai Penelitian Tanah,.

Dewi, G., \& Ginting, A. (2012). Antisipasi krisis pangan melalui kebijakan diversifikasi pangan. Jurnal Ekonomi Dan Kebijakan Publik, 3(1), 65-78.

Estu Prihatiningsih, G., Purnomoadi, A., \& Wahyu Harjanti, D. (2015). Hubungan antara konsumsi protein dengan produksi, protein dan laktosa susu kambing Peranakan Ettawa. Jurnal Ilmu-Ilmu Peternakan, 25(2), 20-27. https://doi.org/10.21776/ub.jiip.2015.025.02.03

Finar, I. . (1975). Organic Chemistry Volume 2 Stereochemistry and the chemistry of Natural Products (Fifth Edit; Longman Scientivic and Technical, ed.). Longman Singapore Publishers.

Glendinning, J. . (2000). Australian soil fertility manual. Revised edition. National library of Autralia cataloging-in publishing entry (National library of Autralia cataloging-in publishing entry, ed.). Australia: CSIRO publishing.

Langoy, W., C. Kaunang, dan M. N. (2012). Nilai Nutrisi Jerami Jagung Varietas Hibrida Bisi 2 dan Manado Kuning yang Difermentasi dengan EM4. Eugenia, 8(1).

Marschner, H. (1986). Mineral Nutrition of Higher Plants. London: Academic Press Inc.

Pritchard, S. . and J. S. . (2005). Crop and Environment Change : An introduction to effect of global warming, increasing atmospheric, $\mathrm{CO} 2$ and $\mathrm{O} 3$ concentration and soil salinization on crop physiology and yield. New York: Food Products Press, Inc.

Sudarmaji, S, Bambang Haryono, S. (1997). Prosedur Analisa untuk Bahan Makanan dan Pertanian. Yogyakarta.: Penerbit Liberty.

Winarso, S. (2005). Kesuburan Tanah: Dasar Kesehatan dan Kualitas Tanah. Yogyakarta: Gaya Media.

Ziraida, R. (2010). Usaha Tani Padi dan Jagung Manis pada Lahan Tadah Hujan untuk Mendukung Ketahanan Pangan di Kalimantan Selatan (kasus di kecamatan Landasan, kotamadya Banjarbaru). (Prosiding Pekan Serealia Nasional, ed.). Balai Pengkajian Teknologi Pertanian, Kalimantan Selatan. 